\title{
IS INDIVIDUAL ENTREPRENEURSHIP NECESSITY OR AN OPPORTUNITY IN THE KYRGYZ REPUBLIC? A PANEL STUDY
}

URMATBEK M. TYNALIEVI

International Ataturk-Alatoo University, Bishkek, Kyrgyz Republic

\section{ABSTRACT}

The goal of this research has been to verify the theoretical discussions on the similarities of the Global Entrepreneurship Monitor (GEM) classified opportunity and necessity entrepreneurship across seven regions of Kyrgyz Republic (KR) and its capital, Bishkek city. Individual entrepreneurs with employees (IEWEs) and without employees (IEWOEs) were used as proxy dependent variables for opportunity and necessity entrepreneurship. The independent variables include unemployment rates, poverty rates, microcredit recipients, crime rate and a few others. The study period was from 2002 to 2012. The least squares dummy variable (LSDV) panel data method was employed, using dummies specifically for each region. The findings of this research from a macro perspective did not confirm those similarities. Proxy dependent variables for opportunity and necessity entrepreneurship, IEWEs and IEWOEs, are rarely affected by the same factors.

\section{JEL CLASSIFICATION \& KEYWORDS}

- C12 C23 IEWE - IEWOE KR - REGIONS - INFORMAL SECTOR = PANEL DATA = LSDV

\section{INTRODUCTION}

Much research indicates that entrepreneurship plays an important role in the economies of both developing and developed countries, even when they operate in informa sectors (e.g. Uusitalo, 2001; Smallbone \& Welter, 2012; Williams \& Youssef, 2014). However, entrepreneurship has not been well researched in the context of the post-Sovie transition economies of Central Asia (CA) as part of developing countries. The Kyrgyz Republic (KR), better known as Kyrgyzstan (KG(Z)), was a part of the former Soviet Union as were its neighboring countries in CA Kazakhstan, Tajikistan, Turkmenistan and Uzbekistan. These countries became independent after separation from the former Soviet Union in 1991, and since then their economies have been in transition from centrally planned economies to free markets (Barnes, 2012; Nikitina, 2012) Speaking of this transition, Stark (1996, p. 1018) noted that post-socialist transition is not a transition from plan to marke but 'from plan to clan'. This could be the case in KR as well; however, that was not the focus of this research.

Private property was illegal during Soviet times (Smallbone \& Welter, 2012), which meant almost three generations of the Kyrgyzstany people grew up unfamiliar with the concepts of owning or running a private business or entrepreneuria activities. In fact, Aidis (2005, p. 11) wrote about entrepreneurship in the CIS countries that there is 'no memory of private business'. Yet, data from the 2009 census indicate that, in the overall restructuring of the labor market, the private sector has become an alternative employer to the state (NSC of KR, 2010). Although the development of the private sector was seen as a way out of the economic

\footnotetext{
'urmat.tynaliev@iaau.edu.kg
}

crisis, institutional, structural, and personal factors, such as dependency on the state lingering from Soviet times and difficulty in adjusting to a liberal market setting, have made the entrepreneurship growth difficult.

According to publications by the National Statistical Committee (NSC) of KR (2002-2012), over the last 11 years the share of the average gross value added to the country's Gross Domestic Product (GDP) by entrepreneurship has been $43.05 \%$. The NSC specifically distinguishes the contribution of the owners of small and medium entrepreneurship (SMEs), individual entrepreneurs (IEs) and farmer-entrepreneurs (FEs). At the same time, their share in employment has been $13.7 \%$. These statistics are comparable with the world data on entrepreneurship; for example, the employment share of entrepreneurs in OECD countries is $8 \%$ and their contribution to GDPs makes up about $50-60 \%$ in many countries (Manolova, Brush, \& Edelman, 2007; Wozowczyk \& Massarelli, 2011).

The specific interest of this research has been the IEs (individual FEs and SMEs are not included), as their share in both national GDP and employment has been steadily growing up. Many studies were carried out, either studying entrepreneurship in general, including SMEs, and FEs (e.g. Williams, 2010; Millan, Congregado, Roman, Praag, \& van Stel, 2014; Williams \& Youssef, 2014), or by using the Global Entrepreneurship Monitor (GEM) data (e.g. Verheul, van Stel, \& Thurik, 2006; Cetindamar, Gupta, Esra, Karadeniz, \& Egrican, 2012). This work extends the research by Williams and Youseff (2014) and other related authors using NSC data across provinces of KR from the aggregated macro perspective. GEM has classified entrepreneurship into two types; that of necessity and opportunity (Reynolds, Bygrave, Autio, Cox, \& Hay, 2002; Bosma, Jones, Autio, \& Levie, 2008; Linan, Fernandez-Serrano, \& Romero, 2013). KR is not a participating country in the GEM studies, and this was another reason to use the NSC data only.

Williams \& Youseff (2014) and some other authors argue that this GEM classification of entrepreneurs into necessity and opportunity types is no longer accurate as most of entrepreneurs in transition economies operate in the informal economy. They also claim that this distinction between opportunity and necessity entrepreneurship is oversimplified. For example, Williams \& Youseff (2014) found in their research from Brazil that for "...many informal sector entrepreneurs, participation in this endeavor is a matter of choice, rather than due to lack of choice, such as because they were seeking independence (16.5\%), had experience or skills in the business $(8.4 \%)$, were following family tradition (8.1\%)," (p. 48). In the same fashion, in Smallbone \& Welter's (2003, p. 3) research in Ukraine, Belarus and Moldova, the major 3 reasons for start ups were - "to increase income" (73\%), "independence" (71\%) and "personal fulfillment" (61\%). Only a minority referred to 'unemployment'. Also, Aidis, Welter, Smallbone, \& Isakova (2007) surveyed 297 women and 81 men in Lithuania and 
Ukraine and confirmed the co-existence of both opportunity and necessity in the motivations behind starting an individual entrepreneurship. William and Youssef (2014) pointed out, that this classification is also used in studying "the motives of entrepreneurs operating in the informal economy," (p. 42).

To the author's best knowledge, this is the first known paper to study provincial level entrepreneurial activity in KR. Up to now, entrepreneurship and other related fields have been understudied, both in $\mathrm{KR}$, and in other CA countries. Therefore, the findings of this research may have an important contribution in terms of differentiating the needs and priorities of these two types of entrepreneurship in designing appropriate policies in the transition economy.

Thus, a few hypotheses have been formulated, theorizing about the similarities or differences between necessity and opportunity entrepreneurship, using individual entrepreneurs with employees (IEWEs) and individual entrepreneurs without employees (IEWOEs) as proxy variables in the context of KR as a transition economy. In the next sections, this article seeks to measure empirically the differential impact of various variables on IEs' activities. In doing so, it uses panel data across seven provinces and the capital, Bishkek city of KR from 2002 to 2012. Finally, based on the results, the author discusses the similarities or differences between these two types of entrepreneurship based on the findings of this research and their policy implications as mentioned above.

\section{Provinces and their Peculiarities in KR}

There are seven provinces and two main cities - Bishkek and Osh in KR. Provinces of KR are different in terms of their areas, natural-economic endowments, population size and density as in any other country. In general, the provinces in KR are divided into north (Chui, Issyk-Kul, Naryn and Talas provinces) and south (Batken, Jalal-Abad, and Osh provinces); more industrial bases are located in the north, whereas the south has a more agricultural base (Aiupov, Abdyrashitov, \& Brovko, 2007; Ishenov, 2012).

According to the Draft Concept of Provincial Development of KR (2012), the traditional division of provinces based on their social-economic indicators (living standards, GDP per capita, available services). Based on their share of contribution to the GDP, they are classified as following: More developed or advanced provinces and cities - Bishkek city, Issyk-Kul and Chui provinces; Medium or Moderately developed provinces - Jalal-Abad province and Osh city (Osh province); Weak or Less developed provinces Batken, Naryn and Talas provinces.
This classification was created using traditional macroeconomic indicators. However, the author needs to look into differences in terms of their entrepreneurship growth using these provinces' macro data. The IEWEs ranges from $40 \%$ in the capital city of Bishkek to $0.6 \%$ in the Naryn province. The IEWOEs range is reverse values of IEWEs - the maximum value is in Naryn at $99.4 \%$ and its minimum value is in Bishkek, at $60 \%$. Also, their share in both national GDP and employment has been steadily growing up as mentioned above. For example, in 2012, IEs' contribution to GDP was up from $15.1 \%$ in 2002 to $18 \%$; and from $6.8 \%$ to $13 \%$ in employment respectively. During the same period, IEs' growth in absolute numbers nearly tripled, from 122525 in 2002 to 297895 by 2012.

As can be seen in Table 1 below, there is a significant variation among these provinces in terms of their IEs' contribution to the local and national economy. The table contains six major industries that the IEs are mainly involved in across the provinces of KR. The contribution of SMEship and farmer-entrepreneurs' is not included in these calculations, although they are included in the national GDP. Therefore, these numbers do not match the total amount in the national GDP column. Thus, the mean values of the following six major economic activities of the local IEs over 11 years are given in the table below.

The table above demonstrates that the IEs' share in the volume of industrial output (both work and services) in the country's GDP is low, only $8.15 \%$, whereas construction work is $25.01 \%$, and transportation of cargo and passengers is $78 \%$ and $81.03 \%$ respectively. The latter two demonstrate the important role of the IEs in the Kyrgyz economy. At the same time, IEs' share in the volume of the industrial output (both work and services) in their respective Osh, Talas and Batken provinces'GRP is among the top $-26.1 \%, 23.73 \%$, and $20.07 \%$ respectively. Also, Talas and Batken provinces' share in the national GDP is among the lowest- $4 \%$ and $3.83 \%$ correspondingly. The average poverty level among these provinces differ greatly as well, ranging from $54.44 \%$ in Naryn to $15.28 \%$ in Bishkek city; the unemployment range was from $12.91 \%$ in Batken to $4.81 \%$ in Talas provinces (NSC Living standards, 2013). These uneven development levels indicate the increasing gap among them, including the entrepreneurship activities.

\section{Theoretical Framework and Research Hypotheses}

The above described GEM classification is used as a theoretical base for this research, using two types of individual entrepreneurship studied here: IEs with employees (IEWEs) and IEs without employees (IEWOEs).

\begin{tabular}{|c|c|c|c|c|c|c|c|}
\hline & & $\begin{array}{l}\text { Industrial Output } \\
\text { (Both Work and } \\
\text { Services) }\end{array}$ & $\begin{array}{l}\text { Construct-ion } \\
\text { Work }\end{array}$ & $\begin{array}{l}\text { Trade and Repair of } \\
\text { Cars, Home and } \\
\text { Personal Appliances }\end{array}$ & $\begin{array}{l}\text { Hotel and } \\
\text { Restaurant } \\
\text { Services } \\
\end{array}$ & \begin{tabular}{|l|} 
Cargo \\
Transported
\end{tabular} & $\begin{array}{l}\text { Passengers } \\
\text { Transported }\end{array}$ \\
\hline$\%$ of National GDP & 100 & 8.15 & 25.1 & 54.00 & 40.1 & 78.00 & 81.03 \\
\hline \multicolumn{2}{|c|}{$\begin{array}{l}\text { Province GPP's share in the } \\
\text { national GDP }\end{array}$} & \multicolumn{6}{|c|}{ Individual entrepreneurs contribution in the provinces' GPP by industry as labeled above } \\
\hline Bishkek city & 35.05 & 15.18 & 21.77 & 35.58 & 50.47 & 37.53 & 79.45 \\
\hline Batken province & 3.83 & 20.7 & 18.00 & 74.35 & 47.81 & 68.38 & 61.18 \\
\hline Chui province & 17.18 & 7.20 & 36.61 & 59.74 & 31.44 & 79.52 & 81.25 \\
\hline Issyk-Kul province & 13.45 & 1.39 & 55.02 & 47.93 & 50.35 & 80.37 & 90.53 \\
\hline Jalal-Abad province & 12.29 & 4.20 & 17.50 & 58.12 & 28.87 & 59.11 & 81.16 \\
\hline Naryn province & 3.97 & 12.31 & 11.31 & 77.04 & 41.98 & 88.51 & 87.75 \\
\hline Osh province & 10.24 & 26.10 & 25.15 & 75.22 & 25.2 & 70.37 & 88.87 \\
\hline Talas province & 4.00 & 23.73 & 22.27 & 69.97 & 11.91 & 89.52 & 90.13 \\
\hline
\end{tabular}




\section{IS INDIVIDUAL ENTREPRENEURSHIP NECESSITY OR AN OPPORTUNITY IN THE KYRGYZ REPUBLIC? A PANEL STUDY}

The goal of this research has been to verify the similarities or differences between opportunity and necessity entrepreneurship across provinces of the KR. According to Sternberg \& Bergmann (2003, p. 15), opportunity entrepreneurship is a "good entrepreneurship." Presumably, these types of entrepreneurs are better educated and occur more often in developed countries. In this regard, the author used IEWEs as proxy for the opportunity entrepreneurship. The mean percentage of IEWEs in KR for the study period from 2002 to 2012 is $13.46 \%$.

On the other hand, other authors state that necessity entrepreneurship is a negative factor as far as 'national growth and development are concerned' (Smallbone \& Welter, 2003, p. 4). Seemingly, these types of entrepreneurs are less educated and occur more often in developing countries. This author classifies IEWOEs as necessity entrepreneurship. The mean percentage of IEWOEs in KR for the study period from 2002 to 2012 makes up $86.54 \%$. Williams \& Youseff (2014) found approximately the same percentage distribution of self-employed entrepreneurs or sole-traders $(86.7 \%)$ and entrepreneurs with employees $(13.3 \%)$ working in an informal sector in Brazil.

The peculiarity of the IEs in KR is that majority of individual entrepreneurs operate in the informal sector similar to findings in Smallbone \& Welter's (2012) and Williams \& Nadin's (2012) research. The informal sector is defined as 'economic activities that are not registered in the national accounts and are not subject to formal rules of contract, licensing, labour inspection, reporting and taxation' (International Labour Organization (ILO), 1984). For the purpose of this research, the following definition of informal economy by the Turkey Household labour force survey was used "[h]ousehold unincorporated enterprises paying a lump-sum tax or not paying any tax, and with fewer than 10 persons engaged (agriculture excluded)," (ILO 2013, p. 23).

According to the existing legislature of $K R$, many entrepreneurs receive the status of individual entrepreneur or sole trader without creating any legal entity. They become so by simply purchasing a patent for some entrepreneurial activities. Patents, in turn, are divided into two types voluntary and mandatory, depending on the types of business activities entrepreneurs are involved in (Taxation Service of KR, 2014). The list of these activities are defined by the Kyrgyz legislature. These types of entrepreneurs are not required to maintain even simple bookkeeping. Another contributing factor to the informal economy is, perhaps, the cash economy, where all the financial transactions are conducted using cash payments. Therefore, it is difficult for the tax inspectors and other inspecting agencies to detect these transactions, as they go unrecorded and unreported.

Nevertheless, the activities of the above-mentioned IEs are legal, although they do not report their total earnings to the state for tax, social security or labour law purposes (Williams \& Windebank, 1998; Williams, 2006). As a result, these IEs with or without employees belong to the household or informal sector as defined above. The following industries' share in the informal sector in KR for 2012 was as following: trade, and repair of cars and home and personal appliances alone made up $12.9 \%$ of the GDP, transportation services come next with $2.4 \%$; and construction was $0.9 \%$ (NSC National Accounts, 2013). At the macro level, the estimated volume of non-observable or informal economy grown up from 35.5 billion KGS in 2008 to 61.7 billion KGS in 2012 (Kyrgyz Soms (KGS) exchange rates: 1USD 57 KGS as of October 2014), and its share in GDP has been 18.8 and $19.9 \%$ respectively (NSC National Accounts, 2013).

\section{Unemployment and IEs across provinces of KR}

Unemployment rates are considered an important variable in this research, although there is no clearly defined relationship between unemployment and entrepreneurship. Some research findings have indicated a positive relationship between unemployment rates and business start-ups (Storey, 1991; Parker, 2009), yet other findings demonstrate a negative relationship between them (e.g. Acs \& Mueller, 2008; Thurik, Carree, van Stel, \& Audretsch, 2008).

With the introduction of a market economy as opposed to the previous socialist planned economy, the majority of employment in KR shifted to the private sector. Mainly, these are self-employed workers or those who work in private enterprises, or on their own lands and farms to produce for personal consumption. The share of private sector employment increased from $83.6 \%$ in 2006 to 84.6 in 2009 (NSC Employment, 2011). Another point to note is that $70.4 \%$ of the self-employed were working in the informal sector in 2011 (NSC Employment, 2011, p. 154).

Interestingly, the proportion of employees of enterprises, institutions and organizations decreased from 34\% in 2003 to $31 \%$ in 2011 . However, many self-employed jobs were created, and the number of individuals employed by other individuals significantly increased by 2.4 times (NSC Employment 2011, p. 16). The average official unemployment rate countrywide has been $8.52 \%$ from 2003 to 2011. The graph of the original data below shows the general trend between IEship and unemployment in KR, which is positive.

Figure 1: Relationship between total number of IEs (Log) and unemployment rate, 2002-2012

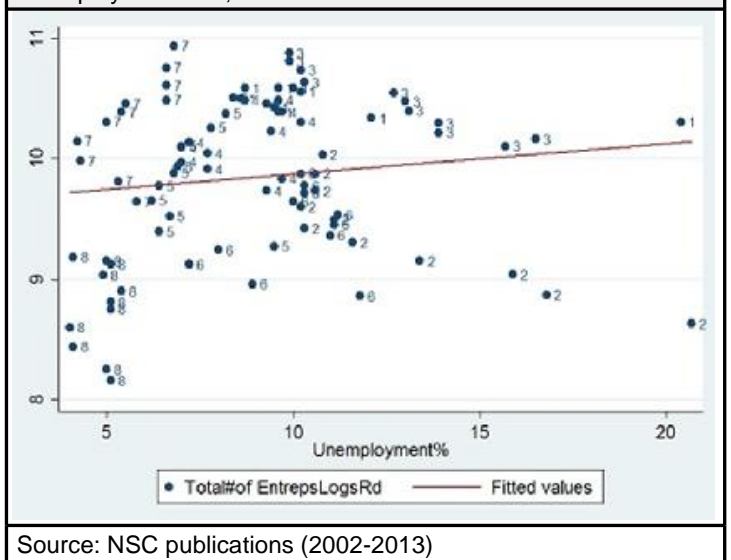

This type of positive relationship between unemployment and entrepreneurship has a relatively 'long research history' (Evans \& Leighton, 1990; Sugheir, Baughn, \& Neupert, 2013 , p. 23). In this sense, the entrepreneurship in KR is seen not only in economic terms, but it also helps to maintain social and political stability in the society and to reduce the tension between unemployed people and the government (Aiupov et al., 2007; Ishenov, 2012).

Thus, the following hypothesis is proposed

Hypothesis 1: The unemployment rate is positively related to the total number of IEs as well as IEWEs and IEWOEs across the provinces and capital city of KR.

\section{Poverty and IEs across provinces of KR}

The poverty rates is another major variable for this research. The role of entrepreneurship in poverty reduction has been 
studied from different aspects (Cohen \& Soto, 2007; World Bank (WB), 2011). However, results have been mixed. Despite the impressive growth of entrepreneurship in $\mathrm{KR}$, the poverty rates have not declined over the years. In fact, the poverty rates grew during last two years (NSC Living Standards, 2013). Perhaps, this is reflected in the graph below.

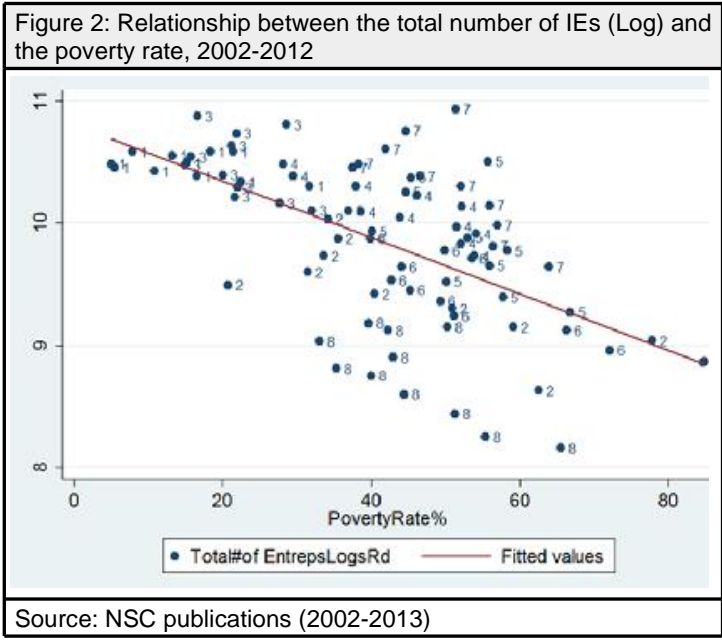

The main reason for poverty among working age people and households in KR is the fall of real income from working i.e. 'frozen' or declining wages and salaries which are not catching up with inflation. In terms of income inequality calculations using quintiles, the richest $20 \%$ of the population owns $47.5 \%$ of monetary income, whereas the poorest $20 \%$ has only $5.2 \%$. Thus, the difference is more than 9 times (NSC Living standards, 2013)

Moreover, given poor people's low skills and social status, they have limited access to financial resources (Peredo \& Chrisman, 2006), which limits their ability to start up a business. All these circumstances exist in $\mathrm{KR}$, and are even exacerbated in some remote and mountainous provinces. For example, the provinces of Batken, Naryn and Talas have very limited access to more prosperous provinces for trade and exchange of goods and services. Perhaps, for the same reasons, these provinces have the highest poverty rates and the fewest number of IEs.

Thus, the following hypothesis was formulated:

Hypothesis 2: The poverty rate in all provinces and capital city is negatively related to the total number IEs, including both IEWEs and IEWOEs.

Microcredit recipients and IEs across provinces of KR

It is well known that access to financial capital can also play a critical role in the growth of entrepreneurship (e.g. Cooper et al., 1994). Conventionally, many start-up entrepreneurs try to borrow money from their friends, family, and relatives as this lending is based on trust and entails almost no interest rates or collateral (Bhide, 1992). However, in the absence of these sources, microcredits become quite a popular means of funding (Khavul, 2010; Yunus, 1999). Usually, microcredits are given to individuals and groups, where group responsibility is used instead of collateral. Therefore, the social capital of individuals becomes an important factor in the acquisition of financial resources (Baker, 2000).
The percentage of the microcredit recipients among the working age population of the most remote provinces Naryn (24.80\%), Talas (22.01\%), and Batken (12.85\%) were the highest. Perhaps, this can be explained by the smaller amount of loans and the group responsibility nature of the microcredits. The latter could also affect the high repayment rate of these microcredits, which ranges from $85 \%$ to $95 \%$. It is noted that the majority of the recipients were women, accounting for $75.75 \%$ over the last 7 years (NSC SMEship, 2013).

There is also an interesting trend that can be easily observed in the structure of microcredits. From 2008 to 2012, more than $50 \%$ of microcredit recipients, received credits for agricultural purposes, rather than for trade or restaurant businesses, as they did early 2000s, when the share of microcredits for trade or restaurants was almost $80 \%$. This can also be explained by the increasing number of long-term microcredits, as opposed to the more prevalent short term ones in the past. This leads to the formulation of the following hypothesis:

Hypothesis 3: Number of recipients of microcredits in provinces and the capital city is positively related to the total number IEs as well as IEWEs and IEWOEs.

Covariates

Entrepreneurs in KG have faced several challenges, including high crime rate as have all post-Socialist environment entrepreneurs. According to NSC (2014) crime against property, including theft of property and livestock is the major part of the crimes in the country. Therefore, crime rate was included as a control variable.

According to these authors (e.g. Kuczi \& Vajda, 1992; Glas \& Petrin, 1998), the entrepreneurs in post-Soviet transition countries have a high education level compared with their western counterparts. For example, Smallbone and Welter (2001, p. 254) noted that ' $80 \%$ of surveyed SMEs in the Ukraine, Belarus and Moldova had owners that were educated to university or higher education level, although this varied from $85 \%$ in Ukraine and Belarus to $54 \%$ in Moldova.' Taking into consideration this, controlling for the university graduates was important

\section{Data and Methods}

As mentioned above, the author used data from the publications of the NSC of KR (2002-2013), related to all seven provinces and the capital city Bishkek of KR for 11 years, available in Kyrgyz and Russian languages. The time frame was restricted to 11 years as no data was available for some provinces before 2002. In fact, the province of Batken was created late 1999, and the statistical data was available only from 2002. The second largest city in the South, Osh, was not included in this research as it was a part of Osh province until 2004, and no separate data was available before 2004 .

Thus, using the data described above, the author studied the differential impact of several independent and control variables on the total number of IEs as well as the IEWEs and IEWOEs across provinces and capital city of KR. To test the hypotheses posed above, the panel data analysis has been used. This method allows the study to compare observations across space (seven provinces and Bishkek city) and over time (11 years) (Wooldridge, 2010). Below more detailed description of dependent, independent and control variables are provided.

Dependent, independent and control variables

As mentioned above, the total number of IEs as well IEWEs as IEWOEs across provinces and the capital city were 


\section{IS INDIVIDUAL ENTREPRENEURSHIP NECESSITY OR AN OPPORTUNITY IN THE KYRGYZ REPUBLIC? A PANEL STUDY}

defined as dependent variables (DVs). This is similar to what GEM has been doing with opportunity and necessity entrepreneurship since its inception. As can be seen in Table 2 below, the independent variables (IVs) include unemployment rates, poverty rates and recipients of microcredits. The control variables are crime rates, and university graduates in the provinces. Provinces' GPP, included initially, was removed at a later stage as it was not a good measurement given the very large share of the informal sector in KR. These variables were discussed in relevant sections above. Many of these variables are used by many researchers across countries and continents (e.g. Osoba, 2009; Khaful 2010; Millan et al., 2014).

\begin{tabular}{|l|l|}
\hline \multicolumn{2}{|l|}{ Table 2: List of dependent and independent variables } \\
\hline Dependent Variable(s) & Independent Variable(s) \\
\hline $\begin{array}{l}\text { Total number of individual } \\
\text { entrepreneurs (IEs) (Log) }\end{array}$ & Unemployment rates (\%) \\
\hline $\begin{array}{l}\text { Individual entrepreneurs with } \\
\text { employees (IEWEs) (Log) }\end{array}$ & Poverty rates (\%) \\
\hline $\begin{array}{l}\text { Individual entrepreneurs without } \\
\text { employees (IEWOEs) (Log) }\end{array}$ & Recipients of microcredits (\%) \\
\hline & Control Variables \\
\hline & $\begin{array}{l}\text { Crime rates (number of } \\
\text { registered crimes) (Log) }\end{array}$ \\
\hline Source: Author & $\begin{array}{l}\text { University graduates (number } \\
\text { of people) (Log) }\end{array}$ \\
\hline
\end{tabular}

Model specification

As mentioned above, panel data analysis was used for this research. Panel or pooled data allows the use of repeated observations (most frequently years) on fixed units (most frequently states, provinces and nations). According to Andreß, Golsch, \& Schmidt (2013), panel or pooled analysis has become central in quantitative studies of comparative political economy and other disciplines.

Panel data allows researchers to control for variables that cannot be observed or measured like cultural factors or differences in business practices across provinces, states, firms, organizations and others as described above. These unobserved individual differences are termed individual heterogeneity (Wooldridge, 2010). The peculiarity of the panel data is that the correlations are expected between error terms for a particular individual/entity across different time periods. In panel data analysis, two popular methods are used most often; fixed effects (FE) and random effects (RE) (Wooldridge, 2010). As the provinces and capital city of KR were not randomly selected for this research, using the FE method is warranted (FE calculations are available from the author).

Within the FE estimator, the least squares dummy variable (LSDV) model allows for unique effects to be controlled for across the cross-sectional elements. The reasoning is that eight cross-sectional observations, i.e. seven provinces and capital city, are individual entities with their own unique sets of cultural, geographical and demographical elements. Each of these elements can create unique incentives for various types of individual behavior, including the decision to engage in entrepreneurship. LSDV can show how the intercepts vary among provinces and capital city. The FE least squares and LSDV can be used interchangeably (Baltagi, 2005).

This is a balanced panel, since the data is available for al years $(\mathrm{T})$ and provinces and the capital city $(\mathrm{N})$. Also, this is a compact panel as it covers consecutive time periods for each individual - there are no "gaps" for any given year from 2002 to 2012. Thus, the final model is as following:

$\mathrm{IES}_{i=}=\alpha_{0}+\mathrm{X}_{i,-1} \beta_{\mathrm{i}}+\alpha_{1}$ Bishkek $_{t}+\alpha_{2}$ Batken $_{t}+\alpha_{3}$ Chui $_{t}+$ $\alpha_{4}$ Issyk-Kul $_{t}+\alpha_{5}$ Jalal-Abad $_{t}+\alpha_{6}$ Naryn $_{t}+\alpha_{7} \mathrm{Osh}_{t}+\alpha_{8}$ Talas $_{t}$ $+a_{i}+\mu_{i t}$

$X_{i, t-1}$ means all the IVs and control variables have a one year lag, because of their delayed effect. All seven provinces and the capital city have their own Dummies or $D_{i}=1$ or $D_{i}=0$ otherwise. However, one of these provinces will be used as a comparison or reference entity for all provinces to avoid perfect multicollinearity; $\alpha_{i}$ are respectively parameter estimates of dummy variables $D_{i}, \beta_{i}$ are parameter estimates of IVs and control variables $\left(X_{i, t-1}\right)$. In these models, $a_{i}$ and $X_{i t}$ are allowed to be correlated, where $a_{i}$ is called a fixed effect that does not vary over time. The advantage of the panel data methods is that it allows the estimation of the parameters consistently using these fixed effects; $\mu_{i t}$ is the error term. Here the constant terms vary by entities, but slopes are the same for all entities. The dummy variables and regressors are also allowed to be correlated in a fixed model (Wooldridge, 2010).

Thus, LSDV models are used to test the hypotheses formulated above and to verify the similarities or differences between necessity and opportunity entrepreneurship in transition economies (Williams \& Youssef, 2014). The significance level to reject a hypothesis is at the $10 \%$ level. The sign of the estimated coefficients should also correspond with the relevant hypotheses.

\section{Results}

Two types of LSDV model tables provided. The first has independent and control variables with provincial dummies; the second model has the interactions of the variables with the microcredits. Thus, five IVs and seven dummies each for a province are used. Chui and Jalal-Abad provinces are used as reference or comparison provinces and omitted in the following two LSDV models respectively. Bishkek city is obviously very different from provinces in terms of its economy, amount of entrepreneurship growth and so on; therefore, it is not used as a reference entity.

\section{LSDV model I analysis}

Table 3 below displays the determinants of the number of IEs across provinces and the capital city of KR using LSDV analysis. We see from the table that a few variables are significant at various levels, either supporting or contradicting their corresponding hypotheses. The negative sign of the unemployment rates across all three DVs is in contradiction with Hypothesis 1 . However, it is strongly significant at $1 \%$ level in relationship to the number of IEWEs only. This indicates that unemployment has a differential effect on IEWEs and IEWOEs, meaning it does not affect much the number of IEWOEs.

The poverty rates has a strong significant effect at $1 \%$ level on the total number of IEs and IEWOEs, and has a negative sign with the same coefficient. This supports Hypothesis 2, although it is not significant in relation to the number of IEWEs and has a positive sign. Microcredit recipients are also strongly significant at the $1 \%$ level with positive signs in relation to the total number of IEs and IEWOEs, which supports Hypothesis 3. However, it is not significant against the number of IEWEs. The crime rates has negative signs across all three DVs, but has a significant effect at $5 \%$ level only on the number of IEWEs. Finally, the results of the university graduates do not have significant effects on all DVs. 
the interaction term between poverty rates and microcredits did not make much difference. The new "combo" variable has only $10 \%$ significance level with the predicted sign in relation to the total number of IEs only.

An unexpected indirect effect of these interaction terms was that the crime rate variable became significant at $5 \%$ and $1 \%$ levels across all three DVs with the negative signs The last "combo" variable between university graduates and microcredits has changed the negative sign to a positive one with the significance level at $1 \%$ in relation to the number of IEWEs only. Nevertheless, this was an important change, as it shows that university graduates with access to finance can contribute to the number of IEWEs. Microcredit recipients also became statistically significant at $1 \%$ and $5 \%$ levels across all DVs, but with one negative sign. An interaction term between poverty rates and microcredits was not successful as discussed above.

Jalal-Abad (a moderately developed province) was used as the reference province in the table above. It was similar to Chui and Osh in relation to the total number of IEs and IEWOEs. Bishkek city was also similar regarding the IEWOEs. Again, we can see a similarity only between more developed (Chui province and Bishkek city) and moderately developed provinces (Jalal-Abad and Osh) mostly in terms of IEWOEs.

\section{Discussions and Policy Implications}

The goal of this research has been to verify the theoretica discussions on the similarities of the GEM classified opportunity and necessity entrepreneurship in transition economies in the KR context. The findings of this research from a macro perspective did not confirm those similarities. Proxy dependent variables for opportunity and necessity entrepreneurship, IEWEs and IEWOEs, are rarely affected by the same factors. Perhaps, a future study may require country level data, as opposed to the provincial or regional data used in this paper. It may be that qualitative research using a micro perspective is needed as well.

As can be seen in the models above, crime rates negatively affect the number of IEs across all provinces. This implies that the law enforcement agencies and the court system are not working well yet. Perhaps this could be one reason for the large share (almost $40 \%$ ) of the shadow economy in the GDP of KR (Kutueva, 2014). Poverty rates have shown a negative effect in these two models, even when used as an interaction term with the microcredits recipients. Perhaps this is because IEWEs need skilled labour rathe than employees chosen solely on the basis of their poverty.

On the positive side, the models have shown that microcredits play an important role in the growth of IEs. Regarding this, two important findings are that unemployed people and university graduates provided with microcredits or some type of funding can contribute positively to the number of IEWEs across provinces. These two categories of people have been the major concern of the government of $\mathrm{KR}$, since there is a large share of the unemployed and higher educated population in KR (NSC Demographic year, 2013). Therefore, facilitating access to finance for the unemployed and university graduates would benefit greatly both sides.

The poverty rates, microcredit recipients and crime rates variables added the most substantial contribution in these two models' explanatory power. The models have also shown that provinces need differentiated policies to boost entrepreneurship growth taking into consideration the particularly differential impact of these three factors.
The traditional division of provinces by their macroeconomic indicators may not yield the desired results.

This research may have a significant conceptual and empirical contribution, as there have been not many studies on these two types of entrepreneurship, IEWE and IEWOE, in the post-Soviet transition economies of CA. Furthermore, this was done at the provincial level within an understudied country, using dummies specifically for each province in a panel data. As far as the author knows this kind of approach is not used very often. Therefore, this could be considered as a methodological contribution, at least within the post-Soviet space.

\section{Conclusion}

Individual entrepreneurs (IEs) have been growing in numbers steadily since the late 1990s, despite the barriers created by political entrepreneurship and looting during two revolutions in KR (2005 and 2010). Political entrepreneurship and the revolutions might be closely related, as the revolutions occurred due to the "predatory and discriminatory" (Zhou, 2011, p. 871) practices of the political ruling elite regarding entrepreneurship in the country. Smallbone \& Welter $(2001$, p. 252) call this "nomenclature entrepreneurship." Perhaps, this could be the reason why most of IEs prefer to operate in the informal sector. After the second revolution in 2010, the political system of the country was changed and KR became the first post-Soviet Parliamentarian system with extensive restrictions of the President's power (Parliament of KR, 2011).

Also, KR became a lower-middle income country in 2014 , after being a low income country since its independence (WB Income Classifications, 2014). There is no doubt that entrepreneurship, including IEs in the informal economy, played an important role in achieving this level of living standards in KR. This has also coincided with the improved ranking of KR from 14 in 2012 to 12 in 2014 in the category of starting a business (WB Doing Business, 2014). These improved rankings signal the growing importance of entrepreneurship and start-ups in the country.

Lastly, a natural and legitimate question is, can these research findings be generalized to other post-Soviet CA countries such as Kazakhstan, Tajikistan, Turkmenistan and Uzbekistan? The answer is no, which could be another limitation of this study. Despite their cultural and historical similarities, these countries are politically and economically very different at this point. This is especially true given the short times series data, available only for 11 years, and the large share of the informal economy in KR. These, perhaps indirectly affected the explanatory power of this study too. In this regard, Taijikistan, Turkmenistan and Uzbekistan may not even have this kind of publicly available datasets. Again, these transition countries, including $\mathrm{KR}$, have been independent only for the last 23 years. Therefore, the findings of this research may have important policy implications in terms of designing sound policies to support the individual entrepreneurship, whose important role in the transition economy of KR is indisputable.

\section{Acknowledgements}

Research for this article was supported in part by the Global Faculty Grants - Research/Publication grant program, which is funded and administered by the Open Society Institute (OSI) under Grant Number IN2013-05104. The grant allowed the author to spend one semester at Naveen Jindal School of Management of the University of Texas at Dallas, United States. The author is also an Affiliate Fellow at 


\section{IS INDIVIDUAL ENTREPRENEURSHIP NECESSITY OR AN OPPORTUNITY IN THE KYRGYZ REPUBLIC? A PANEL STUDY}

CERGE-EI, Prague, Czech Republic. I also thank the following persons for their support: Ms. Zoe Brogden at OSI, and Mr. Michael Jetton and Ms. Deborah Navokova at CERGE-El for their continuous support.

The opinions expressed herein are the author's own and do not necessarily represent the views of OSI or CERGE-EI.

\section{References}

Acs, Z. J., \& Mueller, P. (2008). Employment effects of business dynamics: Mice, gazelles and Elephants. Small Business Economics, 30 (1), 85-100.

Aidis, R. (2005). Entrepreneurship in transition countries: A review. UCL School of Slavonic and East European Studies, Working Pape No. 61. London: University College London.

Aidis, R., Welter, F., Smallbone, D., \& Isakova. N. (2007). Female entrepreneurship in transition economies: The case of Lithuania and Ukraine. Feminist Economics, 13, 157-183.

Aiupov, A. N., Abdyrashitov, A. A., \& Brovko, N. A. (2007) Provinceal'naia Ekonomika [Provincial Economy]. Bishkek: Turar.

Andreß, H. A., Golsch, K., \& Schmidt, A. W. (2013). Applied Pane Data Analysis for Economic and Social Surveys. Berlin: SpringerVerlag.

Baker, W.E. (2000). Achieving Success Through Social Capital: Tapping the Hidden Resources in Your Personal and Business Networks. San Francisco: Jossey-Bass.

Baltagi, B. H. (2005). Econometric Analysis of Panel Data (3rd ed.) UK: John Wiley \& Sons.

Barnes, A. (2012). From the politics of economic reform to the functioning of political economies, Demokratizatsiya, 20, 79-85.

Bhide, A. (1992). Bootstrap finance: The art of start-ups. Harvard Business Review, 70(6), 109-117. Retrieved June 27, 2014, from http://www.eurasiancommission.org/en/Pages/default.aspx.

Bosma, N., Jones, K., Autio, K., \& Levie, J. (2008). Globa Entrepreneurship Monitor: 2007 Executive Report. London: Global Entrepreneurship Monitor Consortium.

Cetindamar, D., Gupta, V. K., Esra, E., Karadeniz, E. E., \& Egrican N. (2012). What the numbers tell: The impact of human, family and financial capital on women and men's entry into entrepreneurship in Turkey, Entrepreneurship and Provincial Development, 24, 29-51.

Cohen, D. \& Soto, M. (2007). Growth and human capital: Good data, good results. Journal of Economic Growth, 12, 51-76.

Cooper, A.C., Gimeno-Gascon, J., \& Woo, C. Y. (1994). Initial human and financial capital as predictors of new venture performance, Journal of Business Venturing, 9(5), 371-395.

Evans, D. S. \& Leighton, L. S. (1990). Small business formation by unemployed and employed workers, Small Business Economics, 2(4), 319-330.

Draft concept of regional development of the Kyrgyz Republic (2012). Proyekt kontseptsii razvitiya regionov Kyrgyzskoy Respubliki. Bishkek: National Academy of Science of the Kyrgyz Republic.

Glas, M. \& Petrin, T. (1998) Entrepreneurship: New challenges fo Slovene women, Frontiers of Entrepreneurship, Babson College. Retrieved June 17, 2014, from: http://fusionmx.babson.edu/ entrep/fer/papers98/V/V D/V D.html.

Ishenov, B. (2012). Kyrgyz Respublikasynyn Provincedorun Onukturuunu Ekonomikalyk Prognozdoo: Teoriyasy, Metodologiyasy jana Praktikasy [Economic Forecasting of Provinces of the Kyrgyz Republic]. Bishkek: Turar.

Khavul, S. (2010). Microfinance: Creating opportunities for the poor? Academy of Management Perspectives, 24(3), 58-72.

Kuczi, T. \& Vajda, A. (1992). Privatization and the second economy, New Hungarian Quarterly, 33, 77-84.

Kutueva, A. (2014). Uroven' Tenevoy Ekonomiki v Kyrgyzstane Sostavlyayet okolo 40 Protsentov [The Level of the Shadow Economy in Kyrgyzstan is about 40 percent]. Available at: www.24.kg (accessed 22 May 2014).
Linan, F., Fernandez-Serrano, J., \& Romero, I. (2013). Necessity and opportunity entrepreneurship: The mediating effect of culture. Revista de Economia Mundial, 33, 21 -47.

Manolova, T. S., Brush, C. G., \& Edelman. L. F. (2007). What do women (and men) want? Entrepreneurial expectancies of women and men nascent entrepreneurs, Frontiers of Entrepreneurship Research, 27, 1-14.

Millan, J. M., Congregado, E., Roman, C., Praag, M., \& van Stel, A. (2014). The value of an educated population for an individual's entrepreneurship success, Journal of Business Venturing, 29, 612-632.

National Statistical Committee of the Kyrgyz Republic. (2010). Provincii Kyrgyzstana

(Provinces of Kyrgyzstan). Bishkek: National Statistical Committee of the Kyrgyz Republic.

National Statistical Committee of the Kyrgyz Republic. (2013). Natsional'nye Scheta Kyrgyzskoy Respubliki 2007 - 2012 [National Accounts of the Kyrgyz Republic 2007-2012]. Bishkek: National Statistical Committee of the Kyrgyz Republic.

National Statistical Committee of the Kyrgyz Republic. (2013). Uroven' Jizni v Kyrgyzskoy Respublike 2007 - 2012 [Living Standards in the Kyrgyz Republic 2007-2012]. Bishkek: National Statistical Committee of the Kyrgyz Republic.

National Statistical Committee of the Kyrgyz Republic. (2013). Maloye i Sredneye Predprinimatel'stvo v Kyrgyzskoy Respublike 2007 - 2012 [Small and Medium Entrepreneurship in the Kyrgyz Republic 2007-2012]. Bishkek: National Statistical Committee of the Kyrgyz Republic

National Statistical Committee of the Kyrgyz Republic. (2007). Maloye i Sredneye Predprinimatel'stvo v Kyrgyzskoy Respublike 2002 - 2006 [Small and medium entrepreneurship in the Kyrgyz Republic 2002-2006]. Bishkek: National Statistical Committee of the Kyrgyz Republic.

National Statistical Committee of the Kyrgyz Republic. (2013). Zanyatost' v Kyrgyzskoy Respublike 2007 - 2012 [Employment in the Kyrgyz Republic 2007-2012]. Bishkek: National Statistical Committee of the Kyrgyz Republic.

Nikitina, Y. (2012). Reflecting on twenty years of post-Soviet experience, Demokratizatsiya, 20(3), 256 -261.

Osoba, B. J. (2009). Culture and entrepreneurial activity in the United States: A quantitative analysis, Innovation-The European Journal of Social Science Research, 22(3), 341-370.

Parker, S. C. (2009). The Economics of Entrepreneurship. UK: Cambridge.

Parliament of KR. (2011). O Parlamente (About Parliament). Retrieved October 17, 2013, from http://www.kenesh.kg/RU/Folders/ 24-O_Parlamente.aspx.

Peredo, A.M. \& Chrisman, J. J. (2006). Toward a theory of community-based enterprise. Academy of Management Review, 31(2), 309-328.

Reynolds, P., Bygrave, W. D., Autio, E., Cox, L.W., \& Hay, M. (2002). Global Entrepreneurship Monitor: 2002 Executive Report. London.

Smallbone, D. \& Welter, F. (2012). Entrepreneurship and institutional change in transition economies: The Commonwealth of Independent States, Central and Eastern Europe and China compared, Entrepreneurship and Provincial Development, 24(3-4), 215-233.

Smallbone, D. \& Welter, F. (2003). Entrepreneurship in transition economies: Necessity or opportunity driven? Retrieved February 12, 2014, from http://www.academia.edu/1024226/Entrepreneurship in transition economies_necessity_or_opportunity_driven.

Smallbone. D. \& Welter, F. (2001). The distinctiveness of entrepreneurship in transition economies, Small Business Economics, 16, 249-262.

Sugheir, J. S., Baughn, C. C., \& Neupert, K. E. (2013). Unemployment and new firm formation during the great recession: The impact of prior levels of entrepreneurship, International Journal of Business and Economics Perspectives, 8, 22-34. 
Sternberg, R. \& Bergman, H. (2003). Global Entrepreneurship Monitor: Länderbericht Deutschland 2002. Germany: Köln.

Storey, D. J. (1991). The birth of new firms - does unemployment matter? A review of the evidence, Small Business Economics, 3, 167-178.

Taxation Service of the Kyrgyz Republic. (2014). Gosudarstvennaya Nalogovaya Sluzhba Kyrgyzskoy Respubliki [Taxation Service of the Kyrgyz Republic]. Retrieved October 7, 2013, from http://www.sti.gov.kg/taxpayers/indiv-entrep\#.

Thurik, A. R., Carree, M. A., van Stel, A. J., \& Audretsch, D. B. (2008). Does self-employment reduce unemployment? Journal of Business Venturing, 23(6), 673-686.

Uusitalo, R. (2001). Homo entreprenaurus? Applied Economics, 33, 1631-1638.

Verheul, I., van Stel, A. J., \& Thurik, R. (2006). Explaining female and male entrepreneurship at the country level, Entrepreneurship and Provincial Development, 18(3), 151- 183.

Williams, C. C. (2010). Spatial variations in the hidden enterprise culture: Some lessons from England. Entrepreneurship and Provincial Development, 22(5), 403-423

Williams, C.C. \& Youssef, Y. (2014) is informal sector entrepreneurship necessity- or opportunity-driven? Some lessons from urban Brazil. Business and Management Research, 3(1), 41-53. Wooldridge, J. M. (2010). Econometric Analysis of Cross Section and Panel Data (2nd ed.). United States: The MIT Press.

World Bank Income Classifications. (2014). Kyrgyz Republic becomes lower middle-income country. Retrieved July 27, 2014, from http://www.worldbank.org/en/news/press-release/2014/07/24/ kyrgyz-republic-becomes-lower-middle-income-country.

World Bank. (2014). Ease of Doing Business in the Kyrgyz Republic. Retrieved July 27, 2014, from http://www.doingbusiness.org/data/ exploreeconomies/kyrgyz-republic/.

World Bank. (2011). World Development Report: Conflict, Security, and Development. Retrieved March 12, 2014, from http://siteresources.worldbank.org/INTWDRS/Resources/WDR2011 Full_Text.pdf.

Wozowczyk, M. \& Massarelli, N. (2011). European Union Labour Force Survey - Annual Results 2010. Retrieved May 14, 2014, from http://epp.eurostat.ec.europa.eu/cache/ITY OFFPUB/KS-SF-11030/EN/KS-SF-11-030-EN.PDF.

Yunus, M. (1999). Banker to the poor. New York: Public Affairs.

Zhou, W. (2011). Provincial deregulation and entrepreneurial growth in China's transition economy. Entrepreneurship and Provincial Development, 23(9-10), 853-876. 